\title{
Deciphering Multifactorial Correlations of COVID-19 Incidence and Mortality in the Brazilian Amazon Basin
}

\author{
Blanca Elena Guerrero Daboin ${ }^{1}$, Italla Maria Pinheiro Bezerra ${ }^{2}\left(\mathbb{D}\right.$, Tassiane Cristina Morais ${ }^{2,3} \mathbb{D}$, Isabella Portugal ${ }^{4} \mathbb{D}$, \\ Jorge de Oliveira Echeimberg ${ }^{5}$, André Evaristo Marcondes Cesar ${ }^{1}$, Matheus Paiva Emidio Cavalcanti ${ }^{1}$, \\ Lucas Cauê Jacintho $^{6}{ }^{\mathbb{D}}$, Rodrigo Daminello Raimundo ${ }^{5}$, , Khalifa Elmusharaf ${ }^{1}$, Carlos Eduardo Siqueira ${ }^{1,7}$ (D) \\ and Luiz Carlos de Abreu 1,3,4,5,*(D)
}

check for updates

Citation: Daboin, B.E.G.; Bezerra, I.M.P.; Morais, T.C.; Portugal, I.; Echeimberg, J.d.O.; Cesar, A.E.M.; Cavalcanti, M.P.E.; Jacintho, L.C.; Raimundo, R.D.; Elmusharaf, K.; et al. Deciphering Multifactorial Correlations of COVID-19 Incidence and Mortality in the Brazilian Amazon Basin. Int. J. Environ. Res. Public Health 2022, 19, 1153. https://doi.org/10.3390/ijerph 19031153

Academic Editors: Tao $\mathrm{Hu}$ Zhenlong Li and Xiao Huang

Received: 3 December 2021

Accepted: 18 January 2022

Published: 20 January 2022

Publisher's Note: MDPI stays neutral with regard to jurisdictional claims in published maps and institutional affiliations.

Copyright: (C) 2022 by the authors. Licensee MDPI, Basel, Switzerland. This article is an open access article distributed under the terms and conditions of the Creative Commons Attribution (CC BY) license (https:// creativecommons.org/licenses/by/ $4.0 /)$.
1 School of Medicine, University of Limerick, V94 T9PX Limerick, Ireland; bgdaboin@yahoo.com (B.E.G.D.); andreemcesar@uol.com.br (A.E.M.C.); mpaivaemidio@gmail.com (M.P.E.C.); khalifa.elmusharaf@ul.ie (K.E.); carlos.siqueira@umb.edu (C.E.S.)

2 School of Sciences of Santa Casa de Misericórdia de Vitória (EMESCAM), Vitoria 29045-402, Brazil; italla.bezerra@emescam.br (I.M.P.B.); tassiane.morais@emescam.br (T.C.M.)

3 Department of Integrated Health Education, Federal University of Espirito Santo, Vitoria 29075-910, Brazil

4 Department of Internal Medicine, School of Medicine, University of Sao Paulo, São Paulo 05403-000, Brazil; iportugal@usp.br

5 Laboratory of Studies Design and Scientific Writing, Postgraduate Division, University Center FMABC, Santo André 09060-870, Brazil; bioredebrasil@gmail.com (J.d.O.E.); rodrigo.raimundo@fmabc.br (R.D.R.)

6 Division of Immunology and Allergy, Department of Medicine, School of Medicine, University of Sao Paulo, São Paulo 05403-000, Brazil; lucas.caue@fm.usp.br

7 Department of Urban Planning and Community Development, School for the Environment, University of Massachusetts Boston, Boston, MA 02125, USA

* Correspondence: luizcarlos@usp.br; Tel.: +55-(11)49935453

\begin{abstract}
Amazonas suffered greatly during the COVID-19 pandemic. The mortality and fatality rates soared and scarcity of oxygen and healthcare supplies led the health system and funerary services to collapse. Thus, we analyzed the trends of incidence, mortality, and lethality indicators of COVID-19 and the dynamics of their main determinants in the state of Amazonas from March 2020 to June 2021 This is a time-series ecological study. We calculated the lethality, mortality, and incidence rates with official and public data from the Health Department. We used the Prais-Winsten regression and trends were classified as stationary, increasing, or decreasing. The effective reproduction number (Rt) was also estimated. Differences were considered significant when $p<0.05$. We extracted 396,772 cases of and 13,420 deaths from COVID-19; 66\% of deaths were in people aged over $60 ; 57 \%$ were men. Cardiovascular diseases were the most common comorbidity $(28.84 \%)$, followed by diabetes $(25.35 \%)$. Rural areas reported $53 \%$ of the total cases and $31 \%$ of the total deaths. The impact of COVID-19 in the Amazon is not limited to the direct effects of the pandemic itself; it may present characteristics of a syndemic due to the interaction of COVID-19 with pre-existing illnesses, endemic diseases, and social vulnerabilities.
\end{abstract}

Keywords: Amazonas; COVID-19; incidence; lethality; mortality; trends

\section{Introduction}

The COVID-19 pandemic has heavily struck Brazil; it has the second highest number of deaths, just behind the United States of America [1]. Since the pandemic began, the circumstances in Brazil have been deeply marked by controversies over the government's response [2]. Actions and implementation of distancing strategies vary from region to region and depend essentially on state governments [3].

Of all 27 Brazilian federative units, Amazonas has suffered the most from the pandemic [4]. After its first SARS-CoV-2 case was reported in Manaus, its capital, on 13 March 2020, 
mortality and fatality rates soared. Manaus has faulty health infrastructure, 293 hospital beds between public and private, and eight ambulances [5]. The lack of oxygen and healthcare supplies led to the deaths of at least 40 patients, not to mention oxygen delivery to remote areas representing another big challenge. Both the health system and funerary services collapsed and as a result, mass graves were dug [6]. These events caused emotional, personal, religious, social, legal, and economic distress for the families of those buried there and the survivors, significantly impacting local communities' mental health and quality of life.

Several factors, including mobility, led to the COVID-19 crisis in Amazonas [7]. In this remote area, the international airport of Manaus has a flow of around three million passengers between arrivals and departures per year [8]. This volume of arrivals is mostly due to the Manaus Free Zone, a tax-reduced area, which has attracted several national and international industries and buyers [9].

Due to its geographical characteristics, ecosystems, flora, and fauna, Amazonas is a national and international tourist attraction for the practice of ecotourism and sportfishing [10]. A recurrent migratory flow from Venezuela, Colombia, and Peru comes through its borders, especially Venezuela. High fluvial mobilization is a characteristic of this region; communities from more remote areas move through its rivers to more urban areas, including indigenous native populations. The fluvial transit is not limited to nationals settled in upper river towns and other Brazilian neighborhoods; the port of Manaus is considered the largest floating one globally; tourist cruises and cargo ships arrive there [11].

Amazonas contains the country's largest group of indigenous people [12]. According to the latest population census, the indigenous population in Amazonas is made up of around 168,000 individuals who are grouped into 62 communities [13].

These heterogeneous people flows come together in a territory labeled one of the most impoverished Brazilian areas [4] with significant income inequality [14]. These existing socioeconomic discrepancies impacted the course of the pandemic, determining poorer outcomes in municipalities with highly vulnerable populations [15], mainly in rural areas.

Specific features of the geographic area where an individual or a community belongs significantly influence the health-disease process. This fact is particularly relevant in the Amazon region due to its abundant water reservoir and extensive green areas. For instance, the state contains 20\% of Earth's freshwater reserves and around 31\% of the planet's tropical forests [16]. However, the urban and rural convergence faces insufficient water and sanitation systems, scarce health resources, and the government's delayed response [17]. Furthermore, the rise in deforestation and the consequent dryness can complicate the COVID-19 pandemic and put the population residing in the Amazon at risk [18].

Fires in the Amazonian territory are responsible for $80 \%$ of the environmental pollution caused by the increase in particulate matter (PM2.5). To Johns Hopkins University [19], the possible relation between contact with PM2.5 and COVID-19 has special significance for public health in Brazil, where incidence and mortality rates are among the highest worldwide. People settled in the North Brazilian region, especially vulnerable communities, are particularly affected by high exposure; for instance, the mortality rate from COVID-19 among indigenous people is above the Brazilian average [20]. Moreover, there is evidence that the reported number of COVID-19 victims among the indigenous population are underestimated [21]. In addition, official data from the Brazilian Ministry of Health show that young adults' mortality increased significantly in the first semester of 2021 compared to the same period of 2020 [22].

Several lineages with a temporal prevalence have been identified in Amazonas. Naveca et al.'s 2021 findings [23] reinforce the idea that consecutive lineage replacements were compelled by a complex mixture of varying grades of social distancing actions and the emergence of a more transmissible virus variant.

We are aware of the importance of monitoring the pandemic in the state of Amazonas, whose number of deaths exceeded 13,000 victims by the end of the first semester of 2021. This number is above what several countries in America and other continents 
have reported [24]. However, several COVID-19 studies on Amazonas focus on the characterization of individuals at a particular time [25]. The analysis and understanding of the temporal variations of COVID-19 mortality and lethality can lead to opportunely and satisfactory interventions for the prevention of more harmful consequences [26-29].

Thus, this study aimed to analyze the incidence, mortality, and lethality indicators of COVID-19 and the dynamics of their main determinants from March 2020 to June 2021.

\section{Materials and Methods}

\subsection{Study Design and Location}

Based on the protocol by Abreu, Emulsharaf, and Siqueira [30] for ecological timeseries studies, we extracted public and official secondary data on cases of and deaths from COVID-19 from the dashboard of the Amazonas State Health Department, Brazil [31].

The state comprises an area of more than 1.5 million $\mathrm{km}^{2}, 18 \%$ of the country's territory, the most extensive of the Brazilian federative units with the lowest population density in the country ( 2.2 inhabitants $\left./ \mathrm{km}^{2}\right)$. However, Manaus, the central urban city and metropolitan area, has around 2 million inhabitants [14].

\subsection{Sampling and Eligibility Criteria}

We included all cases of and deaths from COVID-19 from March 2020 to June 2021. The occurrences were confirmed by laboratory diagnosis; clinical and clinical epidemiological COVID-19 were categorized according to the International Classification of Diseases, 10th edition (ICD-10) as "U07.1 COVID-19, identified virus" or "U07.2 COVID-19, virus not identified", respectively [32].

According to the last day of care, we classified the deaths and cases by symptom onset date. Then, a second author verified the extracted data, and a third researcher made a final check in case of discrepancies. Lastly, the information was written in an Excel spreadsheet (Microsoft Corporation, Redmond, WA, USA) to further analyze the effective reproductive number (Rt), case fatality, mortality, and incidence.

\subsection{Statistical Analysis}

The incidence and mortality rates per 100,000 inhabitants and the case fatality (\%) were determined with Equations (1)-(3). The estimations were based on the number of Amazon state residents in $2020(4,240,210$ inhabitants) [33]:

$$
\begin{aligned}
& \text { Incidence }=\frac{\text { number of cases }}{\text { population }} \times 100,000 \\
& \text { Mortality }=\frac{\text { number of deaths }}{\text { population }} \times 100,000 \\
& \text { Case fatality }=\frac{\text { number of deaths }}{\text { number of cases }} \times 100
\end{aligned}
$$

For trend analysis, the period was divided into two waves: 1st-March to September 2020 and 2nd-October 2020 to June 2021. The trend analysis followed the protocol of Antunes and Cardoso [34]. The time-series were built applying the Prais-Winsten regression model for population mortality rates. It allowed the first-order autocorrelation to analyze time series values and facilitate the assessment and classification of mortality and case fatality into increased, decreased, or flat. Trends were classified as flat when the $p$-value was not significant $(p>0.05)$.

The values for probability $(p)$ and daily percent change (DPC), considering a 95\% level of significance, were calculated using Equations (4)-(6), where $\beta$ is the angular coefficient from the linear regression, the indexes $u l$ mean the upper limit, and $l l$ is the lower limit of the confidence level.

$$
D P C=\left(10^{\beta}-1\right) \times 100 \%
$$




$$
\begin{aligned}
& (C 195 \%)_{u l}=\left(10^{\beta_{\max }}-1\right) \times 100 \% \\
& (C 195 \%)_{l l}=\left(10^{\beta_{\min }}-1\right) \times 100 \%
\end{aligned}
$$

To compare proportions, the two-tailed z-test was used, considering the differences with $p$-value $<0.05$ as significant.

Statistical analyses were performed using the STATA 14.0 software (College Station, TX, USA, 2013). The Rt was estimated using R studio software EpiEstim package [35] version 2.2.4, a time-varying reproduction number for epidemics developed by Thompson and colleagues [36]. As described in previous studies, we used a mean serial interval of 2.97 days with a mean standard deviation of 3.29 days $[37,38]$. Then, we performed a Spearman correlation analysis between Rt and daily new cases, Rt and daily deaths, and Rt and lethality.

\section{Results}

The data indicated 396,772 cases of and 13,420 deaths from COVID-19 during the examined period across different municipalities.

The impact of COVID-19 cases and deaths in the Brazilian Amazon was visible throughout its territory. The number of fatal victims was significantly higher in urban areas, with Manaus accounting for $47 \%$ of cases and $69 \%$ of deaths. The municipalities of Itacoatiara and Iranduba, located near Manaus, registered 17,328 cases and 527 deaths between them (Table 1). However, the virus also reached remote areas where indigenous communities are settled, such as the municipalities of San Gabriel da Cachoeira, Labrea, Antazes, Borba, Barcelos, Atalaia do Norte, and Manicore. Figure 1 illustrates the geographical location of these distant lands that reported 28,059 cases and 524 deaths from COVID-19 and Table 1 indicates the distribution of confirmed cases and deaths by municipality.

\begin{tabular}{|c|c|c|c|c|}
\hline \multirow{2}{*}{ Municipality } & \multicolumn{2}{|c|}{ Cases } & \multicolumn{2}{|c|}{ Deaths } \\
\hline & $n$ & $\%$ & $n$ & $\%$ \\
\hline Alvarães & 2199 & 0.55 & 38 & 0.28 \\
\hline Amaturá & 1227 & 0.31 & 17 & 0.13 \\
\hline Anamã & 1443 & 0.36 & 9 & 0.07 \\
\hline Anori & 1976 & 0.50 & 40 & 0.30 \\
\hline Apuí & 1408 & 0.35 & 31 & 0.23 \\
\hline Atalaia do Norte & 2737 & 0.69 & 13 & 0.10 \\
\hline Autazes & 3366 & 0.85 & 99 & 0.74 \\
\hline Barcelos & 3662 & 0.92 & 64 & 0.48 \\
\hline Barreirinha & 2444 & 0.62 & 64 & 0.48 \\
\hline Benjamin Constant & 3499 & 0.88 & 93 & 0.69 \\
\hline Beruri & 1580 & 0.40 & 33 & 0.25 \\
\hline Boa vista do Ramos & 1029 & 0.26 & 15 & 0.11 \\
\hline Boca do Acre & 2708 & 0.68 & 24 & 0.18 \\
\hline Borba & 2393 & 0.60 & 66 & 0.49 \\
\hline Caapiranga & 618 & 0.16 & 21 & 0.16 \\
\hline Canutama & 1035 & 0.26 & 10 & 0.07 \\
\hline Carauari & 4979 & 1.25 & 54 & 0.40 \\
\hline Careiro & 3949 & 1.00 & 84 & 0.63 \\
\hline Careiro da Várzea & 2587 & 0.65 & 21 & 0.16 \\
\hline Coari & 9400 & 2.37 & 226 & 1.68 \\
\hline Codajás & 3006 & 0.76 & 21 & 0.16 \\
\hline Envira & 3347 & 0.84 & 11 & 0.08 \\
\hline Eurinepé & 3857 & 0.97 & 33 & 0.25 \\
\hline Fonte Boa & 2726 & 0.69 & 35 & 0.26 \\
\hline Guajará & 1577 & 0.40 & 25 & 0.19 \\
\hline Humaitá & 7761 & 1.96 & 103 & 0.77 \\
\hline
\end{tabular}

Table 1. Confirmed cases and deaths by municipalities, Amazonas State, March 2020-June 2021. 
Table 1. Cont.

\begin{tabular}{|c|c|c|c|c|}
\hline \multirow{2}{*}{ Municipality } & \multicolumn{2}{|c|}{ Cases } & \multicolumn{2}{|c|}{ Deaths } \\
\hline & $n$ & $\%$ & $n$ & $\%$ \\
\hline Ipixuna & 4458 & 1.12 & 20 & 0.15 \\
\hline Iranduba & 7510 & 1.89 & 166 & 1.24 \\
\hline Itacoatiara & 9818 & 2.47 & 361 & 2.69 \\
\hline Itamarati & 589 & 0.15 & 7 & 0.05 \\
\hline Itapiranga & 3091 & 0.78 & 39 & 0.29 \\
\hline Japurá & 1045 & 0.26 & 11 & 0.08 \\
\hline Juruá & 1114 & 0.28 & 18 & 0.13 \\
\hline Jutaí & 1843 & 0.46 & 28 & 0.21 \\
\hline Lábrea & 3257 & 0.82 & 82 & 0.61 \\
\hline Manacapuru & 12,447 & 3.14 & 398 & 2.97 \\
\hline Manaquiri & 1582 & 0.40 & 44 & 0.33 \\
\hline Manaus & 186,509 & 47.01 & 9186 & 68.45 \\
\hline Manicoré & 4798 & 1.21 & 93 & 0.69 \\
\hline Maraã & 2206 & 0.56 & 30 & 0.22 \\
\hline Maués & 4508 & 1.14 & 136 & 1.01 \\
\hline Nhamundá & 1821 & 0.46 & 33 & 0.25 \\
\hline Nova olinda do Norte & 1598 & 0.40 & 70 & 0.52 \\
\hline Novo Airão & 2552 & 0.64 & 28 & 0.21 \\
\hline Novo Aripuanã & 1245 & 0.31 & 25 & 0.19 \\
\hline Parintins & 15,176 & 3.82 & 327 & 2.44 \\
\hline Pauini & 2298 & 0.58 & 22 & 0.16 \\
\hline Presidente Figueiredo & 5879 & 1.48 & 113 & 0.84 \\
\hline Rio Preto da Eva & 4254 & 1.07 & 80 & 0.60 \\
\hline Santa Isabel do Rio Negro & 2262 & 0.57 & 46 & 0.34 \\
\hline Santo Antônio do Içá & 2178 & 0.55 & 54 & 0.40 \\
\hline São Gabriel da Cachoeira & 7846 & 1.98 & 107 & 0.80 \\
\hline São Paulo de Olivença & 4095 & 1.03 & 71 & 0.53 \\
\hline São Sebastião do Uatumã & 1074 & 0.27 & 20 & 0.15 \\
\hline Silves & 1438 & 0.36 & 20 & 0.15 \\
\hline Tabatinga & 2831 & 0.71 & 130 & 0.97 \\
\hline Tapauá & 1506 & 0.38 & 11 & 0.08 \\
\hline Tefé & 8670 & 2.19 & 245 & 1.83 \\
\hline Tonantins & 1024 & 0.26 & 25 & 0.19 \\
\hline Uarini & 1868 & 0.47 & 29 & 0.22 \\
\hline Urucará & 2795 & 0.70 & 56 & 0.42 \\
\hline Urucurituba & 3072 & 0.77 & 39 & 0.29 \\
\hline Without municipality identification & 2 & 0.00 & 0 & 0.00 \\
\hline Total & 396,772 & 100.00 & 13,420 & 100.00 \\
\hline
\end{tabular}

On characterizing the infected population in the 62 municipalities of the state of Amazonas, and later by tabulating the data, we verified that age or sex information was missing in 80 cases $(0.02 \%)$ reported by the health secretaries. Therefore, calculations concerning the variables of age and sex were made based on 396,692 cases. Figure 2 splits into graphs A and B and provides details of the distribution by age and sex of the population affected by COVID-19.

Concerning the number of cases (Figure 2a), the virus affected the female population more, with 220,320 cases $(56 \%$ with $p$-value $<0.001)$. The z-test for proportions made it possible to compare the proportions in the number of cases of infected people and deaths by sex and age group.

The proportions of cases were higher in females in the 20-to-29-year-old group ( $p$-value $<0.001)$ and 30 to 39 years $(p$-value $<0.001)$. They were equal in the age groups 0 to 19 years $(p$-value $=0.565)$ and 40 -to-49-year-old $(p$-value $=0.204)$. For the age group 50 years old or more, the proportion of male cases was higher $(p$-value $<0.001)$ 


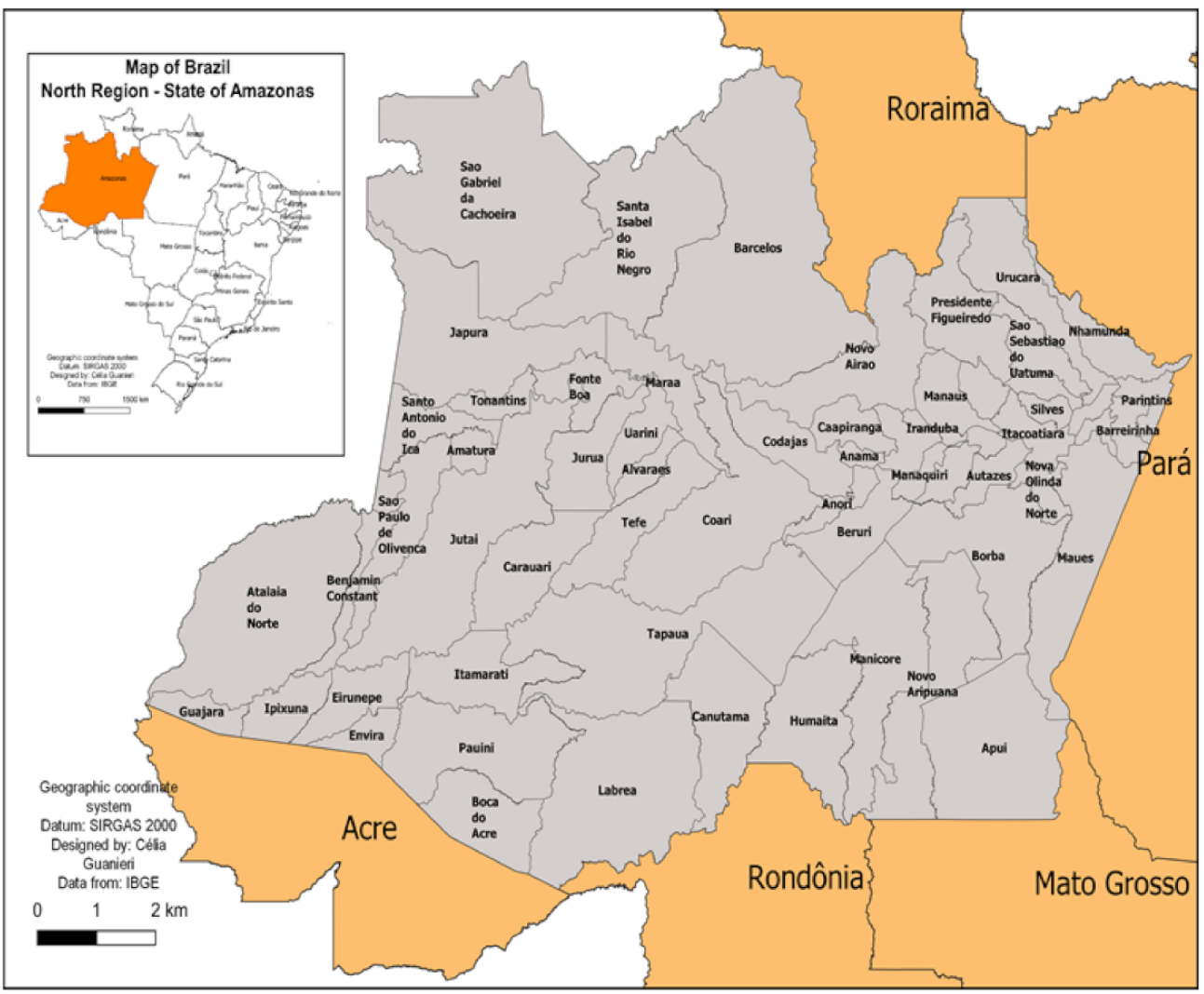

Figure 1. Map of the Amazonas state, indicating its municipalities.

Figure $2 \mathrm{~b}$ indicates that $66 \%$ ( $p$-value $<0.001)$ of deaths occurred in the population over 60 years of age; $57 \%$ were men; there was no significant difference between the proportions of deaths in the two sexes because the lowest $p$-value was 0.162 in this age group. The group aged 50 to 59 accounted for $16 \%$ of deaths, and $60 \%$ were men ( $p$-value $=0.048$ ). Young adults between 20 and 49 years accounted for $6 \%$ of deaths and $59 \%$ were male ( $p$-value $<0.001)$.

Through the z-test, it was possible to compare the confirmed cases group and the group of deaths from COVID-19 in the presence of comorbidities.

By analyzing fatal COVID-19 cases and related comorbidities, notice in Table 2 that cardiovascular diseases (CVD) were most commonly found among deaths with $p$-value $<0.001$ with a proportion equal to $28.84 \%$, followed by diabetes $(25.35 \%)$ and other comorbidities $(25.29 \%)$, respectively with $p$-value $=0.912$.

On the other side, immune-depressed diseases (32.98\%) were the most reported comorbidity ( $p$-value $<0.001)$, followed by CVD $(24.98 \%$ with $p$-value $<0.001)$ and diabetes $(18.75 \%$ with $p$-value $<0.001)$.

The transmissibility of SARS-CoV-2 fluctuated over the period analyzed. The Rt reached its highest value in April 2020 during the first wave and the end of December 2020 during the second wave (Figure 3). The observed values are consistent with the peaks of accumulated cases and their impact on mortality observed in May 2020 and January 2021.

Figure 3 shows the Rt as a function of time for the study period. It showed significant growth between April and May 2020 and another rise in January 2021; for the other months, stationary behavior was observed. This pattern appears similar to the time series of new cases; therefore, correlation analyzes were performed between Rt and daily new cases, Rt and daily deaths, and between Rt and lethality. Table 3 illustrates the results for Spearman's $\rho$ coefficients. 
(a)

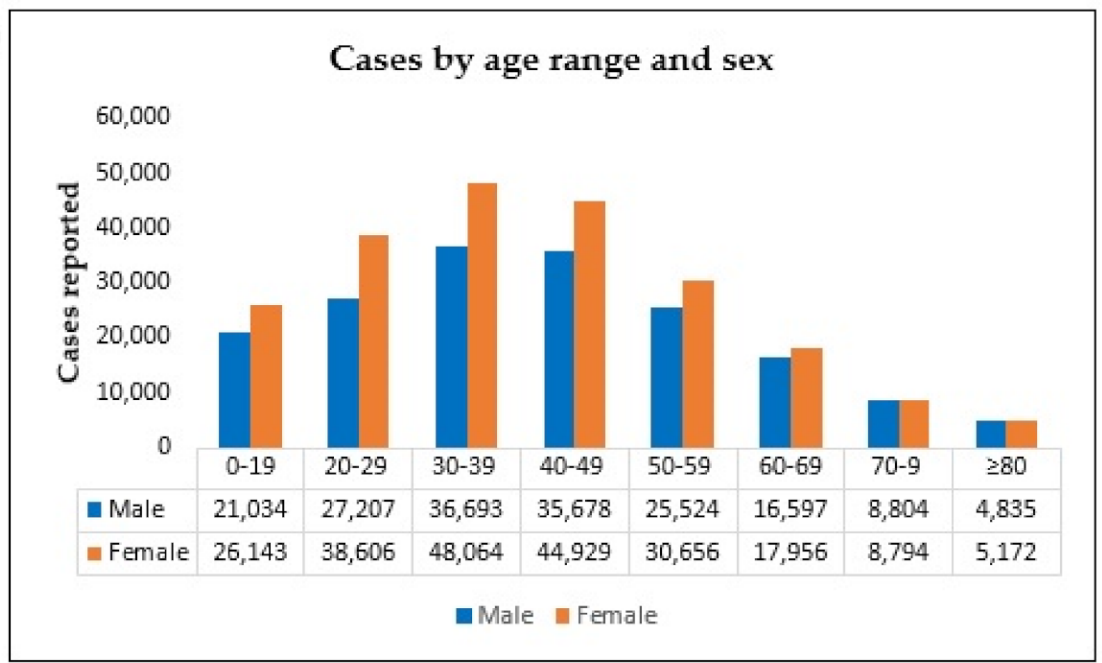

(b)

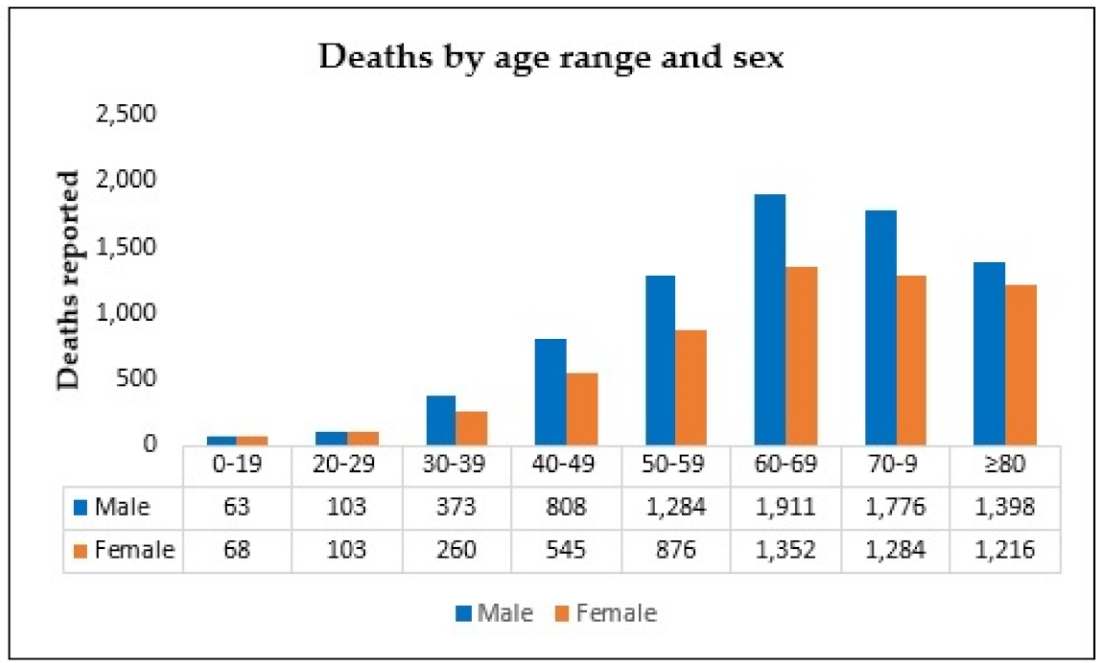

Figure 2. The number of COVID-19 cases (a) and deaths (b) reported by age range and sex in Amazonas State, March 2020-June 2021. Source: Cases and Deaths from the Secretary of Health of the Amazonas State. Note: For the number of cases analysis, 80 cases were excluded by missing information of age or sex.

Table 2. Comorbidities reported by cases and deaths due to COVID-19, in Amazonas State, from March 2020 to June 2021.

\begin{tabular}{|c|c|c|c|c|}
\hline \multirow{2}{*}{ Comorbidity } & \multicolumn{2}{|c|}{ Cases } & \multicolumn{2}{|c|}{ Deaths } \\
\hline & $n$ & $\%$ & $n$ & $\%$ \\
\hline $\begin{array}{l}\text { Chronic obstructive } \\
\text { pulmonary disease }\end{array}$ & 5833 & 6.78 & 545 & 3.98 \\
\hline Cardiovascular disease & 21,502 & 24.98 & 3948 & 28.84 \\
\hline Obesity & 3887 & 4.52 & 768 & 5.61 \\
\hline Down's syndrome & 942 & 1.09 & 46 & 0.34 \\
\hline Hematologic disease & 238 & 0.28 & 97 & 0.71 \\
\hline Immunodepressants & 28,391 & 32.98 & 268 & 1.96 \\
\hline Neurological disease & 716 & 0.83 & 396 & 2.89 \\
\hline Kidney disease & 1462 & 1.70 & 565 & 4.13 \\
\hline Liver disease & 236 & 0.27 & 125 & 0.91 \\
\hline Diabetes & 16,140 & 18.75 & 3471 & 25.35 \\
\hline Other comorbidities & 6735 & 7.82 & 3462 & 25.29 \\
\hline Total & 86,082 & 100.00 & 13,691 & 100.00 \\
\hline
\end{tabular}




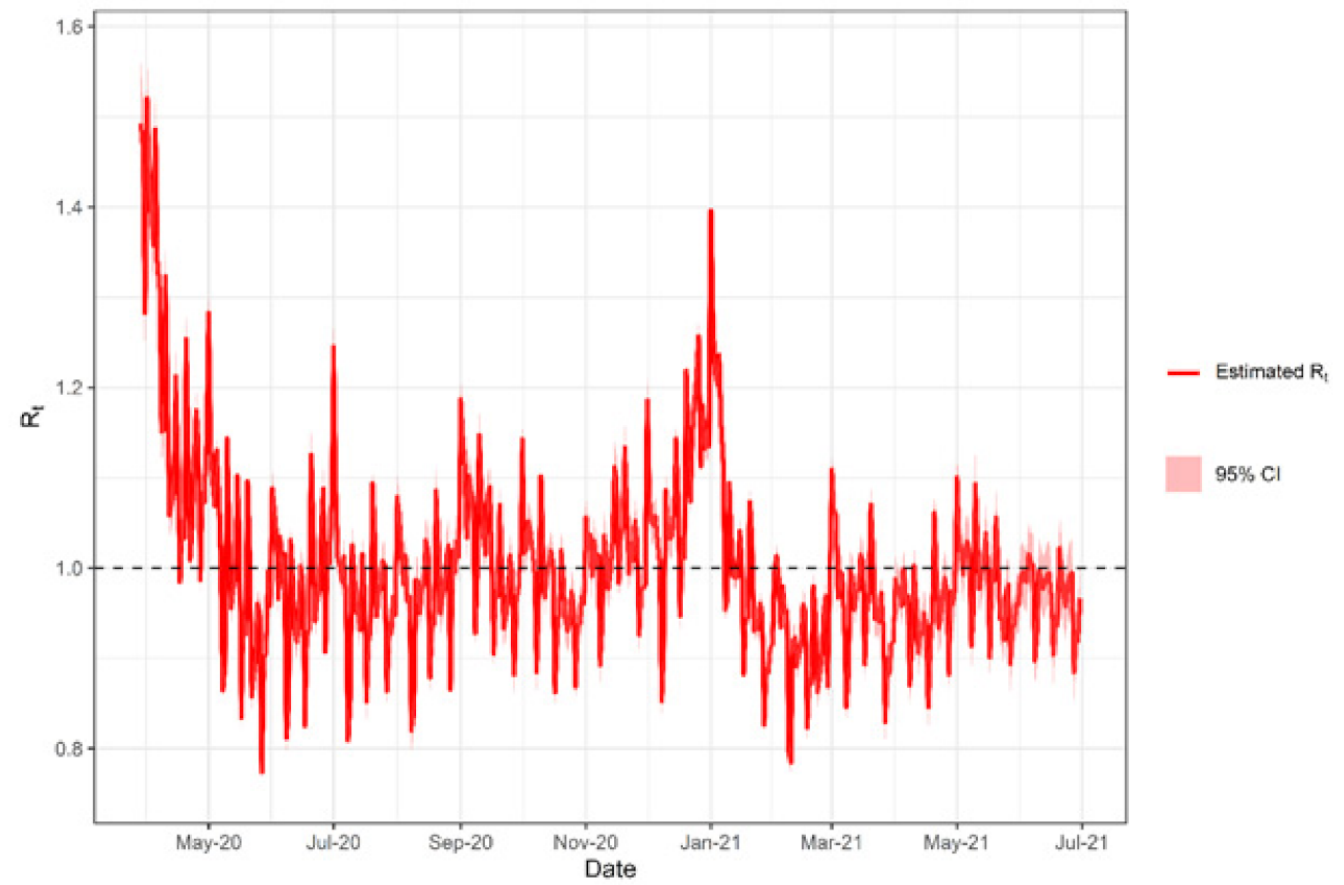

Figure 3. Effective reproduction number (Rt) estimated of COVID-19 from March 2020 to June 2021 in the state of Amazonas, Brazil. $\mathrm{CI}=$ confidence interval. $\mathrm{Rt}=$ effective reproduction number.

Table 3. Study of Spearman's correlation between Rt and lethality, new cases, and deaths.

\begin{tabular}{ccccc}
\hline Analysis & $\rho(\mathbf{C I}$ 95\%) & Freedom Grades & Statistics S & $p$-Value \\
\hline $\mathrm{R}_{\mathrm{t}}$ x case fatality & $\begin{array}{c}-0.334 \\
(-0.412:-0.240)\end{array}$ & 457 & $21,503,589$ & $<0.001$ \\
$\mathrm{R}_{\mathrm{t}}$ × New cases & $\begin{array}{c}0.264 \\
(0.170: 0.349)\end{array}$ & 457 & $11,864,418$ & $<0.001$ \\
$\mathrm{R}_{\mathrm{t}} \times$ Deaths & $\begin{array}{c}-0.076 \\
(-0.163: 0.016)\end{array}$ & 457 & $17,340,448$ & 0.104
\end{tabular}

p-value: the probability of statistical significance. Source: The number of new cases and deaths were extracted from the Department of Health of State of Amazonas, Brazil.

As shown in Table 3, the correlation coefficient between Rt and deaths was not significant; that is, the behavior of the frequency of deaths is not associated with Rt, as expected $(\rho \cong 0)$. There is a positive and significant correlation between Rt and new cases. However, this correlation is not as strong as expected $(\rho \cong 1)$, with the coefficient $\rho=0.264$. For the correlation between Rt and lethality, $\rho=-0.334$ was found, suggesting a significant negative association between Rt and lethality.

Our data revealed two well-defined periods in the pandemic. Table 4 indicates cases, deaths, case fatality (\%), mortality, and incidence rates of COVID-19 per 100,000 inhabitants during the two waves. During the first period, a peak in mortality and incidence occurred in May 2020. Then, the numbers remained stable until September 2020. However, January 2021 was characterized by an exponential increase in cases where the incidence reached its highest number per 100,000 inhabitants. Almost six thousand fatalities were reported between January and February of 2021; the mortality rate peaked in January 2021 (85.84 deaths per 100,000 inhabitants).

Table 5 displays the analyses of incidence, lethality, and mortality trends. During the first wave, incidence rates registered increasing trends, with a DPC of $0.62 \%$, while lethality showed decreasing trends, recording a DPC of $-0.50 \%(p<0.05)$. The incidence trend fell during the second wave with a DPC of $-0.42 \%$, a significant difference. The mortality trends were flat for both waves, with a non-significant $p$-value $(p>0.05)$. 
Table 4. The number of new cases, deaths, case fatality (\%), mortality, and incidence rate by 100,000 inhabitants of COVID-19 in Amazonas State from March 2020 to June 2021.

\begin{tabular}{|c|c|c|c|c|c|c|}
\hline Wave & Date & $\begin{array}{c}\text { New Cases } \\
(n)\end{array}$ & $\begin{array}{c}\text { Deaths } \\
(n)\end{array}$ & $\begin{array}{c}\text { Case Fatality } \\
(\%)\end{array}$ & $\begin{array}{c}\text { Mortality Rate } \\
\text { (per 100,000 } \\
\text { Inhabitants) }\end{array}$ & $\begin{array}{c}\text { Incidence Rate } \\
\text { (per 100,000 } \\
\text { Inhabitants) }\end{array}$ \\
\hline \multirow{7}{*}{ 1st wave } & March & 3734 & 4 & 0.11 & 0.09 & 88.06 \\
\hline & April & 26,121 & 1252 & 4.79 & 29.53 & 616.03 \\
\hline & May & 38,583 & 1612 & 4.18 & 38.02 & 909.93 \\
\hline & June & 27,075 & 522 & 1.93 & 12.31 & 638.53 \\
\hline & July & 23,196 & 325 & 1.40 & 7.66 & 547.05 \\
\hline & August & 17,290 & 265 & 1.53 & 6.25 & 407.76 \\
\hline & September & 21,598 & 263 & 1.22 & 6.20 & 509.36 \\
\hline \multirow{9}{*}{ 2nd wave } & October & 19,747 & 397 & 2.01 & 9.36 & 465.71 \\
\hline & November & 18,456 & 341 & 1.85 & 8.04 & 435.26 \\
\hline & December & 33,572 & 532 & 1.58 & 12.55 & 791.75 \\
\hline & January & 75,037 & 3640 & 4.85 & 85.84 & 1769.65 \\
\hline & February & 34,334 & 2254 & 6.56 & 53.16 & 809.72 \\
\hline & March & 23,909 & 925 & 3.87 & 21.81 & 563.86 \\
\hline & April & 13,620 & 530 & 3.89 & 12.50 & 321.21 \\
\hline & May & 11,868 & 311 & 2.62 & 7.33 & 279.89 \\
\hline & June & 8632 & 247 & 2.86 & 5.83 & 203.57 \\
\hline Total & $\begin{array}{l}\text { March } 2020 \text { to } \\
\text { June } 2021\end{array}$ & 396,772 & 13,420 & 3.38 & 316.49 & 9357.37 \\
\hline
\end{tabular}

$n=396,772$ cases and 13,420 deaths due COVID-19. 1st wave: from March to September of 2020. 2nd wave: from October 2020 to June 2021. Source: Cases, deaths were extracted from the Secretary of Amazonas.

Table 5. Prais-Winsten regression estimates and DPC of case fatality (\%) mortality and incidence rate by 100,000 inhabitants of COVID-19 in the state of Amazonas, during the 1st wave (March to September 2020) and the 2nd wave (October 2020 to June 2021).

\begin{tabular}{|c|c|c|c|c|c|c|c|c|c|}
\hline Period & $\begin{array}{c}\text { DPC } \\
\text { (CI 95\%) } \\
\text { Case Fatality }\end{array}$ & $p$ & $\begin{array}{l}\text { Fatality } \\
\text { Trends }\end{array}$ & $\begin{array}{c}\text { DPC } \\
\text { (CI 95\%) } \\
\text { Mortality }\end{array}$ & $p$ & $\begin{array}{l}\text { Mortality } \\
\text { Trend }\end{array}$ & $\begin{array}{c}\text { DPC } \\
\text { (IC 95\%) } \\
\text { Incidence }\end{array}$ & $p$ & $\begin{array}{l}\text { Incidence } \\
\text { Trend }\end{array}$ \\
\hline 1st wave & $\begin{array}{c}-0.50 \\
(-0.80 ;-0.20)\end{array}$ & 0.001 & Decreasing & $\begin{array}{c}0.96 \\
(-0.54 ; 2.48)\end{array}$ & 0.208 & Flat & $\begin{array}{c}0.62 \\
(0.12 ; 1.11)\end{array}$ & 0.014 & Increasing \\
\hline 2nd wave & $\begin{array}{c}0.22 \\
(0.03 ; 0.41)\end{array}$ & 0.022 & Increasing & $\begin{array}{c}-0.20 \\
(-0.81 ; 0.42)\end{array}$ & 0.534 & Flat & $\begin{array}{c}-0.42 \\
(-0.68 ;-0.17)\end{array}$ & 0.001 & Decreasing \\
\hline
\end{tabular}

DPC—-daily percent change (\%); CI 95\%—confidence interval 95\%; $p$-value-the probability of statistical significance. Statistical difference detected by the Prais-Winsten regression test, $p<0.05$. Source: Number of cases and deaths were extracted from the Secretary of Health of Amazonas, Brazil.

\section{Discussion}

The ability to examine the spread rate, mortality, fatality, and factors that affect these indicators is essential to understanding the trends of the COVID-19 pandemic. We analyzed the scenario from demographic, geographical, and socioeconomic perspectives.

The projection for the population [33] indicates that $57 \%$ are under 30 years old. The age composition reflects an expansive population pyramid shape in which $38 \%$ are aged $0-19$ years, $19 \%$ are $20-29,15.8 \%$ are $30-39,12 \%$ are $40-49,7.9 \%$ are $50-59$, and $4.5 \%$ are 60-69 years. Less than $3 \%$ of the population is 70 years or older.

During the examined period, Amazonas faced two critical episodes, the first in May 2020, reaching 1615 deaths and 36,123 new cases. The second even worse critical peak was in January 2021, when the number of deaths and number of cases were almost double those of May 2020, which led to a collapse of the local health system. These findings coincide with published evidence [23].

From May to the first week of December 2020, fatalities decreased to values very similar to the Brazil national average, varying between $2 \%$ and $3 \%$. During those seven months, the hospitalizations in Manaus had low variation [39], influenced by an increase in 
the number of beds and the implementation of better protocols in primary care and the experience gained by health professionals to attend the most severe cases [40].

Then, politicians, health authorities, and the population relaxed prevention measures during Christmas because the population was "relatively protected". Moreover, the findings of Buss et al. [6] indicate that $70 \%$ of the Manaus population had already been infected with COVID-19, which theoretically would imply herd immunity.

However, according to Ferrante et al. [41], Manaus had a confirmed case of reinfection and immunity loss with SARS-CoV-2 with the same virus lineage. In July 2020, a patient tested positive and the symptoms of reinfection with an aggravated condition were observed in October. Even with severe disease, IgG antibodies were not present in this patient, suggesting that he did not acquire natural immunity to SARS-CoV-2, minimizing the expectations of herd immunity both during the first infection and reinfection.

The accelerated increment of confirmed cases by COVID-19 began by the end of December 2020. It generated a critical effect on the number of fatalities in January 2021, influenced by a new, much more aggressive variant, with P1 being the most predominant.

A sequence of variants has marked the state of Amazonas; a genomic survey conducted from 16 March 2020, to 13 January 2021, revealed several lineages with a temporal prevalence in 25 municipalities of Amazonas, Brazil [23]. The survey reported that the lineage B.1.195 was the most prevalent during the peak experienced in late April and early May during the first wave. Its presence declined, and by the end of May, it was replaced by B.1.1.28, which prevailed until December 2020. Those mutations may allow the coronavirus to disseminate quickly by contact from person to person, and more infections can cause more individuals to get sick or die.

Galvão et al. [42] previously mentioned that the crisis experienced in Manaus and its nearby cities with the COVID-19 pandemic might be a consequence of this region's limited health structure and social vulnerability. However, high mortality rates have been reported in cities of high-income countries [42]. Thus, this may suggest the existence of crucial determinants in COVID-19 morbimortality that are specific to the Brazilian Amazon, such as air pollution, fire seasons, and deforestation.

\subsection{Quality of Air and Deforestation}

Exposure to smoke from forest fires in the Amazon impacts the health of populations most at risk, including those with chronic heart or lung diseases, older adults, children, pregnant women, and fetuses [43]. Remarkably, air pollution has been proven to significantly impact morbidity and mortality from cardiovascular outcomes [44], mainly ischemic heart disease and stroke, which are the most prevalent comorbidity among COVID-19 deaths worldwide and in Amazonas, as mentioned in our results.

A study from the Imperial college and international collaborators [45] found that $76 \%$ of the Manaus population was infected by SARS-CoV-2 between March and October 2020, while in São Paulo, the percentage of people infected was $29 \%$. The new, more contagious variant and the alert of reinfections put extreme pressure on the health system. The variant, known as P.1 or VOC202101/02 in the U.K., was first detected in January 2021 in Japan in people who visited Manaus. This variant has several mutations, including E484K and N501Y. It involves 17 unique amino acid changes, three deletions, four synonymous (silent) mutations, and one 4 nt insertion.

The interaction between weather, nature, and people's actions is a crucial determinant in Amazonian fires. Human-induced fires have been occurring in the Brazilian Amazon since the late 1980s [46,47]. Most of them happen between July and November, during the dry period, rising in September for the south of the basin [48]. Dryness grows the fire risk due to reduced groundwater and soil moisture [49]. Utilizing water surface temperature in the Atlantic and Pacific sea, statistical models predict fire activity [50]. Nevertheless, such prognostications based only on climate miss the vital function of people across the Amazon.

Local populations have been consistently exposed to PM2.5 for over 30 years, characterizing long-term harmful exposure to this air pollutant as observed in previous studies 
in the Amazon [51] and Equatorial Asia [52,53]. Our findings reveal that most of the fatal victims $(66 \%)$ were people older than 60 years; most of them $(57 \%)$ were males. Consistently, research among the Brazilian regions reported that mortality in Manaus in people older than 70 years was double that in Rio de Janeiro and three times that of São Paulo. The most common comorbidities were CVDs and diabetes, similar to those reported in other studies worldwide [54,55].

Freitas et al. [56] observed an increase in the incidence of COVID-19 among younger adults during the second wave (January 2021). We identified that six percent of deaths occurred in adults between 20 and 49 years; 56\% of the male sex. In this study, we did not identify the risk factors by age group. Nonetheless, research from the FVS-AM (Amazon Health Surveillance Foundation) during the first quarter of 2021 reported obesity as the main comorbidity among people who develop severe COVID-19 and die in the age range of 20-39 years [57].

In addition, the emergence of long-term effects among people who have suffered from COVID-19 has been documented. A systematic review reported more than 50 conditions in post-COVID-19 patients [58]. This suggests that the high mortality [59] and COVID-19 sequelae can potentially decline life expectancy.

Our analysis indicates that the scenario changed from an incidence-increasing trend during the first wave to a decrease during the second one. The growing evolution of first wave incidence remained constant until March 2021. The growth in the number of cases was deeply affected by the lack of non-pharmacological measures, such as social distancing [60] and the use of face masks. On the other hand, particularly in Brazil, the lack of a national clinical guideline makes it challenging to evaluate the reasons for high mortality from COVID-19, mainly in intubated patients.

The incidence of COVID-19 in Amazonas was marked by a decreasing trend at the end of June 2021, which suggests the positive effect of the vaccination program. It began in mid-January 2021. Older adults, people with disabilities, health professionals, and the indigenous population were within the priority group [61]. By the end of February, more than $60 \%$ of indigenous people over 18 had received the first dose [62].

The trend in mortality was stable for both defined waves. On the other side, the lethality decreased in the first wave to an increasing trend in the second wave. In this scenario, the number of COVID-19 tests was focused on severe patients, which suggests that the percentage of deaths could be higher than that reported [63].

The reduction in deaths from March 2021 is associated with prevention measures and the closure of non-essential businesses, especially in Manaus and its surroundings, where more than $50 \%$ of the state's population is concentrated. In addition, the state of Amazonas became a priority in the national vaccination program [61]. Research by Orellana et al. [64] reported an excess of 312\% (95\% CI 304-321) among 46,028 deaths from respiratory causes that occurred in eight cities from February 23 to August 08, 2020. Manaus recorded the highest excess of mortality, with 758\% (95\% CI 668-858), and São Paulo the lowest, with $174 \%$ (95\% CI 164-183). The significant differences among the cities reinforce the regional inequalities in health access aggravated by the lack of a national clinical protocol and suggest a potential underreporting of deaths due to COVID-19.

The maximum level of transmission, represented by the number of cases and deaths, was first reached in the northern region [40]. Thus, the epidemiological situation of the Amazon is of great concern. Before the pandemic, the health coverage problems and insufficient hospital beds, intensive care beds, and ventilators were already evident public health issues in this territory. The pandemic was a fuel that more starkly evidenced those limitations; Manaus, the capital, is the only city with intensive care units (ICU). A study by the Brazilian Association of Orthomolecular Medicine on the evolution of patients treated with invasive mechanical ventilation due to COVID-19 indicated that mortality in the Amazon was $88.5 \%$, while that of the south and southeast of the country was $76.8 \%$. However, in some reference hospitals in São Paulo the mortality rate in intubated patients fluctuated from $30 \%$ to $45 \%$ [65]. 


\subsection{Territorial Variables Affecting the COVID-19 Crisis in Amazonas State}

The limitations of access to health care and the social disparities in Northern Brazil have been decisive in the complex situation of high incidence and high mortality in Amazonas. However, as pointed out by Fundação Oswaldo Cruz [40], the daunting scenario reveals a combination of factors that favored the spread of this virus (Figure 4) and essentially justified the high incidence and mortality found in this state.

First, the state of Amazonas shares borders with Colombia, Venezuela, and Peru. Brazil delayed closing its borders to control the spread of the virus. A significant population of migrants, mainly from Venezuela, works in the informal economy, mainly as street vendors in Manaus. They are a group that does not comply with quarantine and distancing rules.

Second, the largest indigenous population in Brazil is concentrated in this state. Additionally, other communities such as river dwellers and descendants of former slaves (quilombolas) are settled in distant areas on the banks of the rivers [66]. They are highly vulnerable and face constant threats from illegal mining and logging in the Amazon rainforest. Miners and loggers are potential carriers of the virus and can infect rural communities [2]. The paradoxical high mortality in these sparsely populated areas may be attributable to the deficient sanitation and communal use of water reservoirs, in addition to crowded boats making transport through the rivers benefit the spread of the virus [17].

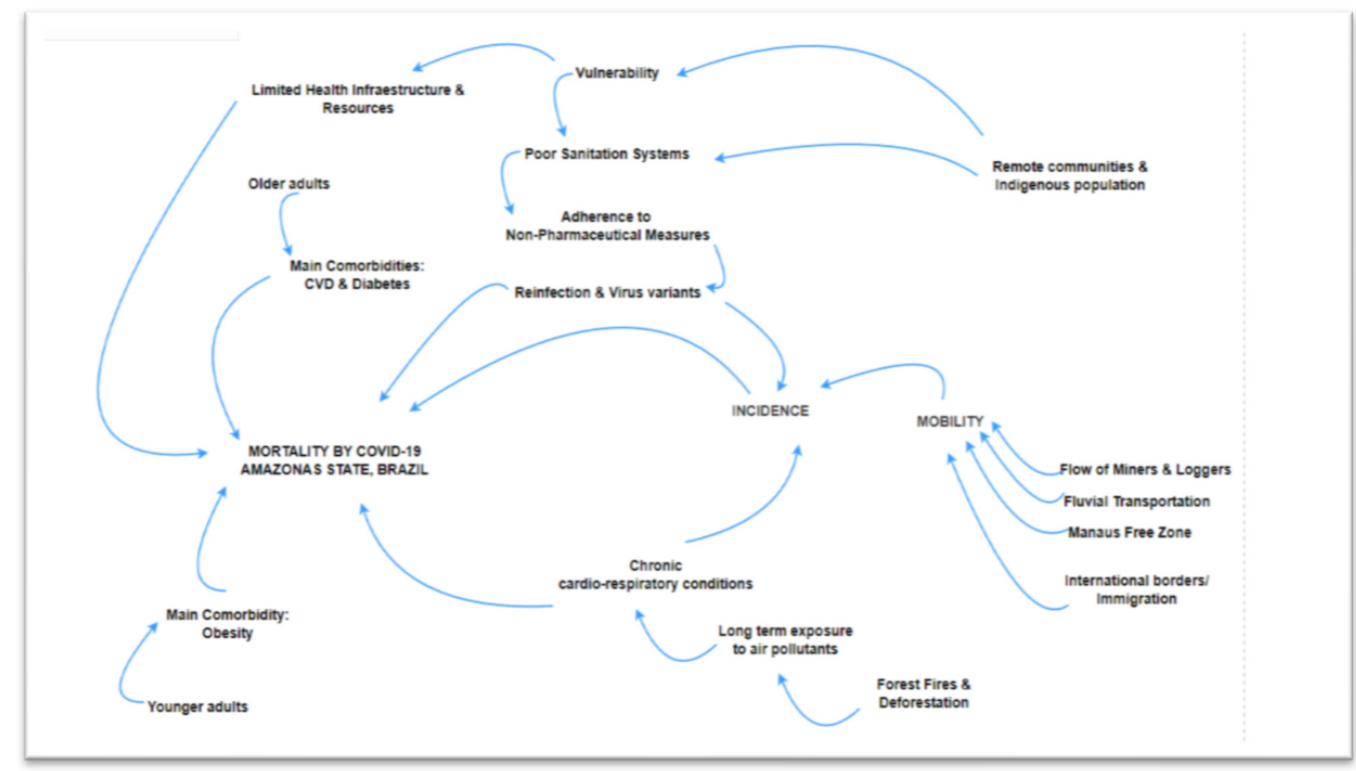

Figure 4. Cause consequence diagram of factors affecting mortality by COVID-19 in Amazonas State, March 2020-June 2021.

According to the Brazil Indigenous People Articulation [67] the first death of an indigenous person was in Amazonas. Up to 30 April 2021, this state experienced 254 indigenous deaths - the highest in the country.

Third, the Manaus Free Zone has international companies and frequently receives people from abroad. As mentioned, variant P.1 was identified in Japan among travelers who had visited Manaus. Later, this variant was identified in patient samples collected in January 2021 [68].

Fourth, Amazonas is an endemic area for Malaria and Dengue, which have some symptoms similar to COVID-19. Additionally, there is evidence of co-infection of SARSCoV-2 with dengue [69]. This syndemic context makes the detection and treatment of COVID-19 complex in the region.

This study may present limitations inherent to secondary databases, such as alterations in terms of residence, which can cause distortions in the numbers of cases and deaths by city or municipality. 
The results presented are partial data since the pandemic is still being analyzed. The data were consolidated based on the last day's report, but these may have been reported late. The number of accumulated cases may be higher, considering the limitations of doing massive tests to detect the disease. Hence, it is pertinent to mention potential discrepancies between the reported incidence and the actual number of people infected with the virus.

\section{Conclusions}

The impact on mortality and incidence by COVID-19 in the Amazon is not limited to harm generated by the pandemic. Various region-specific factors may have significantly contributed to the Brazilian Amazon's complex scenario during the COVID-19 pandemic, such as poor sanitation systems, dependence on communal water reservoirs, and long-term exposure to air pollutants due to forest fires. Furthermore, it may present the characteristics of a syndemic due to the interaction of pre-existing diseases and social vulnerability.

Our results highlight the importance of systematic and persistent efforts to research and develop interventions seeking environmentally sustainable development of the Brazilian Amazon and improvements in healthcare quality and access to socioeconomically vulnerable populations. Hence, it is essential to carry out systematic population studies with pandemic data to support prevention and control strategies.

Author Contributions: Conceptualization, L.C.d.A., B.E.G.D. and I.M.P.B.; methodology, C.E.S., J.d.O.E., K.E., L.C.d.A. and R.D.R.; software, L.C.J.; validation, J.d.O.E. and M.P.E.C.; formal analysis, T.C.M., I.M.P.B., J.d.O.E. and L.C.J.; investigation, B.E.G.D., I.P., A.E.M.C. and R.D.R.; data curation, T.C.M., B.E.G.D. and A.E.M.C.; writing—original draft preparation, all authors; writing—review and editing, all authors; visualization, T.C.M. and M.P.E.C.; supervision, L.C.d.A., C.E.S. and K.E.; project administration, L.C.d.A., I.M.P.B., R.D.R. and T.C.M. All authors have read and agreed to the published version of the manuscript.

Funding: This research received no external funding.

Institutional Review Board Statement: Not applicable.

Informed Consent Statement: Not applicable.

Data Availability Statement: Data were extracted from a population database in a COVID-19 dashboard, freely accessible on the Health Department of the State of Amazonas website: http:/ / saude.am. gov.br/painel/corona/ (accesed on 19 July 2021).

Acknowledgments: To the staff of the Laboratório de Delineamento em Estudos e Escrita Científica, Centro Universitário FMABC, especially Celia Guarnieri, for her support in designing the maps, and Henrique Moraes Ramos da Silva for his contribution to access the platforms of secondary data.

Conflicts of Interest: The authors declare no conflict of interest.

\section{References}

1. World Health Organization. WHO Coronavirus (Covid-19) Dashboard. Available online: https://covid19.who.int/ (accessed on 15 July 2021).

2. The Lancet. COVID-19 in Brazil: "So what?". Lancet 2020, 395, 1461. [CrossRef]

3. University of Miami. COVID-19 Observatory. Public Polity Adoption Index in Brazil. Available online: http://observcovid. miami.edu/brazil/ (accessed on 22 June 2021).

4. Hallal, P.C.; Hartwig, F.P.; Horta, B.L.; Silveira, M.F.; Struchiner, C.J.; Vidaletti, L.P.; Neumann, N.A.; Pellanda, L.C.; Dellagostin, O.A.; Burattini, M.N.; et al. SARS-CoV-2 antibody prevalence in Brazil: Results from two successive nationwide serological household surveys. Lancet. Glob. Health 2020, 8, e1390-e1398. [CrossRef]

5. Governo do Estado do Amazonas. Boletim diário COVID-19 No Amazonas 22/7/2020. Available online: http:/ /www.fvs.am. gov.br/media/publicacao/22_07_20_BOLETIM_DI\%C3\%81RIO_DE_CASOS_COVID-19_1.pdf (accessed on 23 July 2020).

6. $\quad$ Buss, L.F.; Prete, C.A., Jr.; Abrahim, C.; Mendrone, A., Jr.; Salomon, T.; de Almeida-Neto, C.; França, R.; Belotti, M.C.; Carvalho, M.; Costa, A.G.; et al. Three-quarters attack rate of SARS-CoV-2 in the Brazilian Amazon during a largely unmitigated epidemic. Science 2021, 371, 288-292. [CrossRef]

7. Ribeiro, S.P.; Castro e Silva, A.; Dáttilo, W.; Reis, A.B.; Góes-Neto, A.; Alcantara, L.; Giovanetti, M.; Coura-Vital, W.; Fernandes, G.W.; Azevedo, V. Severe airport sanitarian control could slow down the spreading of COVID-19 pandemics in Brazil. PeerJ 2020, 8, 9446. [CrossRef] 
8. Movimento de Passageiros No Aeroporto de Manaus Cresce e Chega a 3 Milhões. Available online: https://amazonasatual.com. br/movimento-de-passageiros-no-aeroporto-de-manaus-cresce-e-chega-a-3-milhoes/ (accessed on 22 June 2021).

9. Ministério da Economia. Zona Franca de Portas Abertas. Available online: https://www.gov.br/suframa/pt-br/zfm/zonafranca-de-portas-abertas (accessed on 22 June 2021).

10. Amazonastur. Programa de Infraestrutura Turística. Available online: http:/ /www.amazonastur.am.gov.br/programas-e-acoes/ (accessed on 15 July 2021).

11. Jacobs, W.; Pegler, L.; Reis, M.; Pereira, H. Amazon shipping, commodity flows and urban economic development: The case of Belém and Manaus. Cad. Metrop. 2013, 15, 389-410. [CrossRef]

12. Santos, R. Com 13 Novos Casos, Amazonas Tem 67 Pessoas Infectadas Pelo Novo Coronavírus-Secretaria de Estado de Saúde do Amazonas. 2020. Available online: http:/ / www.saude.am.gov.br/visualizar-noticia.php?id=4375.Portuguese (accessed on 20 July 2021).

13. Meneses-Navarro, S.; Freyermuth-Enciso, M.G.; Pelcastre-Villafuerte, B.E.; Campos-Navarro, R.; Meléndez-Navarro, D.M.; Gómez-Flores-Ramos, L. The challenges facing indigenous communities in Latin America as they confront the COVID-19 pandemic. Int. J. Equity Health 2020, 19, 63. [CrossRef]

14. Instituto Brasileiro de Geografia e Estatística. Cidades e Estados. Available online: https://www.ibge.gov.br/cidades-e-estados (accessed on 18 June 2021).

15. Rocha, R.; Atun, R.; Massuda, A.; Rache, B.; Spinola, P.; Nunes, L.; Lago, M.; Castro, M.C. Effect of socioeconomic inequalities and vulnerabilities on health-system preparedness and response to COVID-19 in Brazil: A comprehensive analysis. Lancet. Glob. Health 2021, 9, e782-e792. [CrossRef]

16. Davidson, E.A.; de Araújo, A.C.; Artaxo, P.; Balch, J.K.; Brown, I.F.; Bustamante, M.M.; Coe, M.T.; DeFries, R.S.; Keller, M.; Longo, M.; et al. The Amazon basin in transition. Nature 2012, 481, 321-328. [CrossRef]

17. Ramírez, J.D.; Sordillo, E.M.; Gotuzzo, E.; Zavaleta, C.; Caplivski, D.; Navarro, J.C.; Crainey, J.L.; Bessa Luz, S.L.; Noguera, L.; Schaub, R.; et al. SARS-CoV-2 in the Amazon region: A harbinger of doom for Amerindians. PLoS Negl. Trop. Dis. 2020, 14, e0008686. [CrossRef] [PubMed]

18. De Oliveira, G.; Chen, J.M.; Stark, S.C.; Berenguer, E.; Moutinho, P.; Artaxo, P.; Anderson, L.O.; Aragão, L. Smoke pollution's impacts in Amazonia. Science 2020, 369, 634-635. [CrossRef] [PubMed]

19. Johns Hopkins Universityimore (MD): The University. Dashboard by the Center for Systems Science and Engineering (CSSE). Available online: https:/ / coronavirus.jhu.edu/map.htm (accessed on 10 April 2021).

20. Marlier, M.E.; Bonilla, E.X.; Mickley, L.J. How do Brazilian fires affect air pollution and public health? Geohealth 2020, 4, e2020GH000331. [CrossRef]

21. Fellows, M.; Paye, V.; Alencar, A.; Nicácio, M.; Castro, I.; Coelho, M.E.; Silva, C.; Bandeira, M.; Lourival, R.; Basta, P.C. Underreporting of COVID-19 cases among indigenous peoples in Brazil: A new expression of old inequalities. Front. Psychiatry 2021, 12, 638359. [CrossRef]

22. Brasil. Ministério da Saúde. Painel Coronavírus. Available online: https:/ / covid.saude.gov.br/ (accessed on 7 November 2021).

23. Naveca, F.G.; Nascimento, V.; de Souza, V.C.; Corado, A.L.; Nascimento, F.; Silva, G.; Costa, Á.; Duarte, D.; Pessoa, K.; Mejía, M.; et al. COVID-19 in Amazonas, Brazil, was driven by the persistence of endemic lineages and P.1 emergence. Nat. Med. 2021, 27, 1230-1238. [CrossRef]

24. Panamerican Health Organization. COVID Daily Update. Available online: https://iris.paho.org/bitstream/handle/10665.2/54 468/COVID-19DailyUpdate30June2021_eng.pdf?sequence=1\&isAllowed= (accessed on 30 June 2021).

25. Valbuena-Garcia, A.M.; Rodriguez-Villamizar, L.A. Análisis espacial en epidemiología: Revisión de métodos. Rev. Univ. Ind. Santander. Salud 2018, 50, 358-365.

26. Cesar, A.E.M.; Daboin, B.E.G.; Morais, T.C.; Portugal, I.; Echeimberg, J.O.; Rodrigues, L.M.R.; Jacintho, L.C.; Raimundo, R.D.; Elmusharaf, K.; Siqueira, C.E. Analysis of COVID-19 mortality and case-fatality in a low-income region: An ecological time-series study in Tocantins, Brazilian Amazon. J. Hum. Growth. Dev. 2021, 31, 496-506. [CrossRef]

27. Guarnieri, C.S.; Sousa, L.V.A.; Paiva, L.S.; Morais, T.C.; Ribeiro, M.A.L.; Ribeiro, M.R.; Monteiro, C.B.M. COVID-19 mortality and lethality in the State of Pará, legal Amazon, Brazil. J. Hum. Growth Dev. 2021, 31, 398-404. [CrossRef]

28. Lima, D.L.; Morais, T.C.; Daboin, B.G.; Cavalcanti, M.P.E.; Mesaroch, A.; Silva, H.M.R.; Silva, C.G.; Monteiro, C.B.M.; Abreu, L.C. Epidemiological perspective of the evolution of the COVID-19 pandemic in Amapá State, Northern Brazil. J. Hum. Growth Dev. 2021, 31, 414-424. [CrossRef]

29. Valenzuela, E.V.; Morais, T.C.; Daboin, B.G.; Cavalcanti, M.P.E.; Portugal, I.B.M.; Souza, I.S.S.; Ribeiro, M.A.L.; Monteiro, C.B.M.; Abreu, L.C. Evolution of mortality and lethality due to COVID-19 in the State of Roraima, Brazil, from March 2020 to July $2021 . J$. Hum. Growth Dev. 2021, 31, 447-457. [CrossRef]

30. De Abreu, L.C.; Elmusharaf, K.; Siqueira, C.E.G. A time-series ecological study protocol to analyze trends of incidence, mortality, lethality of COVID-19 in Brazil. J Hum Growth Dev. 2021, 31, 495-499.

31. Secretaria de Saude do Estado de Amazonas. Painel Covid-19 Amazonas. Available online: http://saude.am.gov.br/painel/ corona/ (accessed on 20 April 2021).

32. World Health Organization. International Statistical Classification of Diseases and Related Health Problems 10th Revision. Available online: https:/ /icd.who.int/browse10/2019/en\#/U04 (accessed on 20 June 2021). 
33. Datasus. Informações de Saúde (TABNET)—Demográficas e Socioeconômicas—População Residente. 2021. Available online: http: / / www2.datasus.gov.br/DATASUS/index.php?area=0206\&id=6942 (accessed on 20 June 2021).

34. Antunes, J.L.F.; Cardoso, M.R.A. Uso da análise de séries temporais em estudos epidemiológicos. Epidemiol. Serv. Saúde 2015, 24, 565-576. [CrossRef]

35. Cori, A.; Ferguson, N.M.; Fraser, C.; Cauchemez, S. A new framework and software to estimate time-varying reproduction numbers during epidemics. Am. J. Epidemiol. 2013, 178, 1505-1512. [CrossRef] [PubMed]

36. Thompson, R.N.; Stockwin, J.E.; van Gaalen, R.D.; Polonsky, J.A.; Kamvar, Z.N.; Demarsh, P.A.; Dahlqwist, E.; Li, S.; Miguel, E.; Jombart, T.; et al. Improved inference of time-varying reproduction numbers during infectious disease outbreaks. Epidemics 2019, 29, 100356. [CrossRef]

37. Ali, S.T.; Yeung, A.; Shan, S.; Wang, L.; Gao, H.; Du, Z.; Xu, X.K.; Wu, P.; Lau, E.; Cowling, B.J. Serial intervals and case isolation delays for COVID-19: A systematic review and meta-analysis. Clin. Infect. Dis. 2021, ciab49. [CrossRef]

38. Prete, C.A.; Buss, L.; Dighe, A.; Porto, V.B.; da Silva Candido, D.; Ghilardi, F.; Pybus, O.G.; de Oliveira, W.K.; Croda, J.H.R.; Sabino, E.C.; et al. Serial interval distribution of SARS-CoV-2 infection in Brazil. J. Travel Med. 2021, 28, 115. [CrossRef]

39. Sabino, E.C.; Buss, L.F.; Carvalho, M.; Prete, C.A.; Crispim, M., Jr.; Fraiji, N.A.; Pereira, R.; Parag, K.V.; da Silva Peixoto, P.; Kraemer, M.; et al. Resurgence of COVID-19 in Manaus, Brazil, despite high seroprevalence. Lancet 2021, 397, 452-455. [CrossRef]

40. Fiocruz 2020. Observatorio COVID-19 -Boletim-Um Balanço da Pandemia 2020. Available online: https://portal.fiocruz. br/documento/boletim-do-observatorio-covid-19-edicao-especial-faz-balanco-da-pandemia-no-brasil-em-2020 (accessed on 22 June 2021).

41. Ferrante, L.; Livas, S.; Steinmetz, W.A.; Almeida, A.; Leão, J.; Vassão, R.C.; Tupinambás, U.; Fearnside, P.M.; Duczmal, L.H. The first case of immunity loss and SARS-CoV-2 reinfection by the same virus lineage in Amazonia. J. Racial. Ethn. Health Disparities 2021, 8, 821-823. [CrossRef]

42. Galvão, T.F.; Tiguman, G.M.B.; Caicedo, R.M.; Silva, M.T. Inequity in utilizing health services in the Brazilian Amazon: A population-based survey, 2015. Int. J. Health Plan. Manag. 2019, 34, e1846-53. [CrossRef] [PubMed]

43. Urrutia-Pereira, M.; Rizzo, L.V.; Chong-Neto, H.J.; Solé, D. Impact of exposure to smoke from biomass burning in the Amazon rain forest on human health. J. Bras. Pneumol. 2021, 47, e20210219. [CrossRef]

44. Cohen, A.J.; Brauer, M.; Burnett, R.; Anderson, H.R.; Frostad, J.; Estep, K.; Balakrishnan, K.; Brunekreef, B.; Dandona, L.; Dandona, R.; et al. Estimates and 25-year trends of the global burden of disease attributable to ambient air pollution: An analysis of data from the Global Burden of Diseases Study 2015. Lancet 2017, 389, 1907-1918. [CrossRef]

45. Luisetto, M.; Naseer, A.; Khaled, E.; Fiazza, C.; Ahmed Yesvi, R.; Ghulam, R.; Latishev, O. Research article deforestation, air pollution and Brazilian COVID-19. JCIM 2021, 2, 1-19.

46. Alencar, A.A.; Brando, P.M.; Asner, G.P.; Putz, F.E. Landscape fragmentation, severe drought, and the new Amazon forest fire regime. Ecol. Appl. 2015, 25, 1493-1505. [CrossRef]

47. Giglio, L.; Randerson, J.; Van der Werf, G. Analysis of daily, monthly, and annual burned area using the fourth-generation global fire emissions database (GFED4). JGR Biogeosci. 2013, 118, 317-328. [CrossRef]

48. Chen, Y.; Morton, D.C.; Jin, Y.; Collatz, G.J.; Kasibhatla, P.S.; van der Werf, G.R.; DeFries, R.S.; Randerson, J.T. Long-term trends and interannual variability of forest, savanna and agricultural fires in South America. Carbon Manag. 2013, 4, 617-638. [CrossRef]

49. Ray, D.K.; Gerber, J.S.; MacDonald, G.K.; West, P.C. Climate variation explains a third of global crop yield variability. Nat. Commun. 2015, 6, 5989. [CrossRef]

50. Lima, C.; AghaKouchak, A.; Randerson, J. Unraveling the role of temperature and rainfall on active fires in the Brazilian Amazon using a nonlinear poisson model. JGR Biogeosci. 2018, 123, 117-128. [CrossRef]

51. Butt, E.W.; Conibear, L.; Knote, C.; Spracklen, D.V. Large air quality and public health impacts due to Amazonian deforestation fires in 2019. GeoHealth 2021, 5, e2021GH000429. [CrossRef]

52. Crippa, P.; Castruccio, S.; Archer-Nicholls, S.; Lebron, G.B.; Kuwata, M.; Thota, A.; Sumin, S.; Butt, E.; Wiedinmyer, C.; Spracklen, D.V. Population exposure to hazardous air quality due to the 2015 fires in Equatorial Asia. Sci. Rep. 2016, 6, 37074. [CrossRef]

53. Kiely, L.; Spracklen, D.; Wiedinmyer, C.; Conibear, L.; Reddington, C.; Arnold, S.; Knote, C.; Md Khan, F.; Latif, M.; Syaufina, L.; et al. Air quality and health impacts of vegetation and peat fires in Equatorial Asia during 2004-2015. Env. Res. Lett. 2020, 15, 094054. [CrossRef]

54. Onder G, Rezza G, Brusaferro, S. Case-fatality rate and characteristics of patients dying with COVID-19 in Italy. JAMA 2020, 323, 1775-1776. [CrossRef]

55. Pachiega, J.; Afonso, A.; Sinhorin, G.T.; Alencar, B.T.; Araújo, M.; Longhi, F.G.; Zanetti, A.; Espinosa, O.A. Chronic heart diseases as the most prevalent comorbidities among deaths by COVID-19 in Brazil. Rev. Inst. Med. Trop. Sao Paulo 2020, 62, e45. [CrossRef] [PubMed]

56. Freitas, A.R.R.; Beckedorff, O.A.; de Góes Cavalcanti, L.P.; Siqueira, A.M.; de Castro, D.B.; da Costa, C.F.; Queiróz Lemos, D.R.; Barros, E.N.C. The emergence of novel SARS-CoV-2 variant P.1 in Amazonas (Brazil) was temporally associated with a change in the age and sex profile of COVID-19 mortality: A population based ecological study. Lancet Reg. Health Am. 2021, 1, 100021. [CrossRef] 
57. Fundação de Vigilância em Saúde do Amazonas. Boletim Diário de Covid-19 n. 482. Available online: http:/ /www.amazonas.am. gov.br/2021/07 / cenario-epidemiologico-da-covid-19-no-amazonas-e-divulgado-pela-fvs-rcp-nesta-sexta-feira-3007/ (accessed on 20 July 2021).

58. Lopez-Leon, S.; Wegman-Ostrosky, T.; Perelman, C.; Sepulveda, R.; Rebolledo, P.A.; Cuapio, A.; Villapol, S. More than 50 long-term effects of COVID-19: A systematic review and meta-analysis. Sci. Rep. 2021, 11, 16144. [CrossRef]

59. Castro, M.C.; Gurzenda, S.; Turra, C.M.; Kim, S.; Andrasfay, T.; Goldman, N. Reduction in life expectancy in Brazil after COVID-19. Nat. Med. 2021, 27, 1629-1635. [CrossRef]

60. Leal-Neto, O.B.; Santos, F.; Lee, J.Y.; Albuquerque, J.O.; Souza, W.V. Prioritizing COVID-19 tests based on participatory surveillance and spatial scanning. Int. J. Med. Inf. 2020, 143, 104263. [CrossRef] [PubMed]

61. Secretaria Municipal de Saúde. Plano Municipal de Operacionalização da Vacinação Contra a COVID-19. Available online: https:/ /semsa. manaus.am.gov.br/wp-content/uploads/2021/01/PROPOSTA-COVID-181220-versa\%CC\%83o-1.1-1.pdf (accessed on 20 August 2021).

62. Covid-19: Over 60\% of Indigenous People with More Than 18 Years Old Were Vaccinated. Available online: https:// agenciabrasil.ebc.com.br/saude/noticia/2021-02/covid-19-60-dos-indigenas-maiores-de-18-anosja-receberam-vacina (accessed on 15 March 2021).

63. França, E.B.; Ishitani, L.H.; Teixeira, R.A.; Abreu, D.; Corrêa, P.; Marinho, F.; Vasconcelos, A. Deaths due to COVID-19 in Brazil: How many are there and which are being identified? Rev. Bras. Epidemiol. 2020, 23, e200053. [CrossRef] [PubMed]

64. Orellana, J.; Marrero, L.; Horta, B.L. Excess deaths from respiratory causes in eight Brazilian metropolises during the first six months of the COVID-19 pandemic. Cad. Saude Publica 2020, 37, e00328720. [CrossRef]

65. Asociacion Brasileira de Medicina Ortomolecular. Qual Poderia Ser a Maior Causa de Mortalidade Associada à Covid-19? Available online: http:/ / ambo.com.br/qual-poderia-ser-a-maior-causa-de-mortalidade-associada-a-covid-19/ (accessed on 29 October 2021).

66. Penna, G.; Pinto, L.F.; Soranz, D.; Glatt, R. High incidence of diseases endemic to the Amazon region of Brazil, 2001-2006. Emerg. Infect. Dis. 2009, 15, 626-632. [CrossRef] [PubMed]

67. Emergencia Indigena. Dados Covid-19. Available online: https://emergenciaindigena.apiboficial.org/dados_covid19/ (accessed on 22 June 2021).

68. Ministry of Health. Boletim Epidemiológico Especial. Doença do Coronavírus COVID-19—Semana Epidemiológica 8 (21 a 27/2/2021). Available online: https://www.gov.br/saude/pt-br/media/pdf/2021/marco/05/boletim_epidemiologico_covid_ 52_final2.pdf (accessed on 22 June 2021).

69. Quental, K.N.; Leite, A.L.; Feitosa, A.D.N.A.; Oliveira, Z.N.P.; Tavares, L.V.S.; Tavares, W.G.S.; Pinheiro, E.F.; Lacsina, J.R.; DeSouza-Vieira, T.; Silva, J.B.N.F. SARS-CoV-2 co-infection with dengue virus in Brazil: A potential case of viral transmission by a health care provider to household members. Travel Med. Infect. Dis. 2021, 40, 1-3. [CrossRef] 